\title{
POTENSI LIMBAH KERANG SERIMPING SEBAGAI SUMBER KALSIUM UNTUK PEMELIHARAAN DENSITAS TULANG
}

\author{
Safira Firdaus, Anissa Indah Cahyati, Ria Wahyu Dwi Nastiti, dan Siti Aminah \\ Fakultas IImu Keperawatan dan Kesehatan, Jurusan Teknologi Pangan, Universitas Muhammadiyah \\ Semarang, Jl. Kedungmundu Raya No. 18 Semarang, Telp. (024) 76740296, \\ email: saffiragustus@gmail.com
}

\begin{abstract}
ABSTRAK
Cangkang kerang serimping yang ditepungkan memiliki kandungan $17,23 \%$ kalsium yang dapat dimanfaatkan sebagai sumber kalsium. Agar dapat dimanfaatkan secara optimal, tepung cangkang kerang serimping harus difortifikasikan dengan tepung jagung yang mengandung sumber fosfor. Tujuan penelitian ini adalah mengkaji kandungan kalsium pada sereal jagung yang diperkaya tepung cangkang kerang serimping. Penelitian ini bersifat experimental laboratoriesdan deskriptif menggunakan Rancangan Acak Lengkap (RAL) dengan tiga perlakuan. Perlakuan adalah penambahan tepung cangkang kerang serimping pada produk, yaitu control $(0 \%), 5 \%$, dan $10 \%$. Parameter yang diamati adalah kandungan kalsium, fosfor, dan nilai organoleptic. Penambahan tepung cangkang kerang serimping sebanyak $10 \%$ pada sereal jagung merupakan formulasi terbaik dan dapat diterima dari uji organoleptic dari segi aroma, rasa, dan tekstur. Dengan waktu ketahanan kerenyahan dalam susu selama 8 menit 30 detik dan kandungan $\mathrm{Ca} 3,80 \% \mathrm{P}$ $0,14 \%$
\end{abstract}

Kata kunci : kalsium, kerang serimping, sereal jagung

\section{ABSTRACT}

Asian moon scallop (Amusium pleuronectes) is contain 17,23\% of calcium that can be utilized as a source of calcium. In order to be used optimally, scallop shells flour should be added with corn flour containing a source of phosphorus. The purpose of this study is to assess the content of calcium in corn cereal enriched scallop shells flour. This research is experimental laboratories and descriptive using a completely Randomized Design (CRD) with three treatments. Treatment is the addition of scallop shells flour on the product, namely control (0\%), $5 \%$, and $10 \%$. The observed Parameter is the content of calcium, phosphorus, and the value of the organoleptic. The addition of scallop shells flour as much as $10 \%$ on the cereals corn is the best formulation and can be received from the test organoleptic in terms of aroma, flavor, and texture. With time the resistance of crispness in milk for 8 minutes 30 seconds and the content of Ca 3.80.\% P $0,14 . \%$

keywords : calcium, scallop, cornflakes

\section{PENDAHULUAN}

Osteoporosis adalah penyakit kronis yang menyerang manusia, umumnya wanita pada usia lanjut yang disebabkan karena penurunan densitas dan kualitas tulang akibat menurunya produksi hormone estrogen mulai usia 35 tahun. Tulang sebenarnya tidak memiliki kandungan kalsium yang cukup banyak,oleh karena itu dibutuhkan asupan makanan yang mengandung sumber kalsium.

Kalsium termasuk ke dalam salah satu makro elemen yaitu mineral yang dibutuhkan oleh tubuh dalam jumlah yang lebih dari $100 \mathrm{mg}$ sehari. Makro elemen berfungsi sebagai bagian penting dari struktur sel dan jaringan. Kalsium juga memiliki kemampuan absorpsi atau penyerapan yang tinggi pada saat masa pertumbuhan dan mengalami penurunan pada saat mengalami proses penuaan, selain itu absorpsi pada laki-laki dari pada perempuan. Ada beberapa faktor yang mempengaruhi absorpsi kalsium yaitu kelarutan kalsium dalam air dan jenis makanan yang dikonsumsi. Kalsium yang tidak mengalami absorpsi akan dikeluarkan dari tubuh. Sumber kalsium dapat diperoleh dari sayur, tahu, ikan, udang kering, kacang kacangan, dan cangkang kerang serimping.Selain produk olahan susu dan ikan kering, kalsium juga dapat ditemukan di dalam cangkang kerang serimping. Pada cangkang kerang serimping terdapat kalsium sebanyak $17,23 \%$ dan fosfor $0,79 \%$ yang dapat menjadi sumber kalsium potensial (Agustini et al., 2011).

Menurut Ratnawati (2014), Potensi kalsium yang tinggi pada cangkang kerang 
serimping ini dapat dimanfaatkan dengan penambahan tepung jagung atau tepung jawawut yang mengandung fosfor supaya dapat difortifikasikan dalam bentuk makanan. Agar penyerapannya optimal produk yang dapat dikembangkan menurut kami adalah sereal, sehingga apabila dimakan dalam jumlah banyak akan mengurangi tingkat penurunan densitas dan kualitas tulang.

Pemanfaatan cangkang kerang serimping di bidang pangan pernah diteliti oleh Agustini et al (2009) tentang produk berbasis tepung cangkang kerang serimping. Pemanfaatan di bidang pangan dan kesehatan sangat berpotensi untuk dikembangkan jika dilihat dari kandungan gizinya. Cangkangnya yang tipis dan berwarna putih kecoklatan akan memudahkan proses pengolahan.

Flakes atau sereal merupakan makanan ringan berupa lembaran tipis berwarna kuning keemasan serta biasa dikonsumsi sebagai menu sarapan dengan penambahan susu. Penambahan tepung cangkang kerang serimping pada olahan flakes selain memberi inovasi rasa dan meningkatkan nilai ekonomis juga mengandung banyak kalsium dan fosfor yang berguna bagi kesehatan densitas tulang. Diharapkan sereal sarapan dari cangkang kerang serimping dapat dijadikan salah satu bentuk makanan langsung siap saji yang dapat diterima masyarakat sebagai produk inovasi yang berperan untuk pemeliharaan densitas tulang.

\section{METODE PENELITIAN}

\subsection{Alat dan Bahan}

Bahan yang dibutuhkan pada penelitian ini adalah jagung kuning varietas Bisma, diperoleh dari Balai Benih Palawija Gading Gunung Kidul. Cangkang kerang serimpingdidapat dari Pasar Gang Baru dan Pasar Prembaen Kota Semarang, $\mathrm{CH}_{3} \mathrm{COOH} 2 \mathrm{~N}$, aquades.Peralatan yang diperlukan: waskom, cabinet dryer, mortar, diskmill, ayakan, cetakan , loyang,dan oven

\subsection{Metode}

\section{Pembuatan Tepung Cangkang Kerang Serimping}

Proses pembuatan tepung cangkang kerang serimping dilakukan dengan memodifikasi metode. Agustini et al. (2011). Garis besar prosedur pengolahan kerang serimping tinggi kalsium menggunakan metode deproteinase yaitu menghilangkan protein pada cangkang kerang dengan hidrolisis menggunakan asam asetat $2 \mathrm{~N}$ selama 3 jam. Pengeringan cangkang kerang menggunakan cabinet dryer dengan suhu $60^{\circ}$.

\section{Pembuatan Sereal}

Pembuatan sereal dilakukan menggunakan dua metode, yaitu menggunakan noodle maker dan mesin ekstruksi, yaitu mencampurkan semua bahan sesuai dengan fomulasi (Tabel 1). Dihomogenisasi dengan penambahan air dan diuleni hingga kalis. Dilakukan pengukusan adonan, dicetak dilanjutkan dengan pemanggangan sampai sereal berwarna kekuningan menggunakan oven pada suhu $150^{\circ}$ selama 8 menit. Sedangkan prosedur pembuatan sereal menggunakan metode ekstrusi adalah memasukkan cangkang kerang serimping dan jagung yang telah dikecilkan ukurannya ke dalam mesin ekstruder single screw pada suhu $135^{\circ} \mathrm{C}$.

Tabel 1. Formula Sereal Jagung yang Diperkaya dengan Kerang Serimping sebagai Sumber Kalsium

Perlakuan

\begin{tabular}{cccc} 
Komposisi bahan & & & \\
\cline { 2 - 4 } & $\mathbf{0 \%}$ & $\mathbf{5 \%}$ & $\mathbf{1 0 \%}$ \\
\hline Tepung Jagung(gr) & 50 & 45 & 40 \\
Tepung serimping(gr) & 0 & 5 & 10 \\
Tepung tapioca(gr) & 10 & 10 & 10 \\
Susu bubuk(gr) & 10 & 10 & 10 \\
Mentega(gr) & 10 & 10 & 10 \\
Gula halus(gr) & 20 & 20 & 20 \\
Maizena(gr) & 20 & 20 & 20 \\
\hline
\end{tabular}




\section{Rancangan Penelitian}

Rancangan penelitian yang digunakan adalah Rancangan Acak Lengkap (RAL) dengan perbandingan tepung ekstrudat jagung dan tepung serimping yang terdiri dari 3 perlakuan yaitu $0 \%, 5 \%$, dan $10 \%$ dengan tujuh kali pengulangan.

\section{Analisis Data}

Data yang diperoleh dianalisis dengan sidik ragam (ANOVA). Analisis ini digunakan untuk menguji perbedaan nyata dari tiap perlakuan yang dilakukan dalam penelitian. Apabila terdapat suatu perbedaan maka dilanjutkan dengan pengujian Beda Nyata Jujur (BNJ). Sebelum analisis ANOVA dilakukan, terlebih dahulu dilakukan uji kadar kalsium menggunakan metode AAS. Data hasil uji organoleptic diuji menggunakan Non Parametric Friedman dan dilanjutkan menggunakan Wilcoxon.

\section{HASIL DAN PEMBAHASAN}

Hasil analisis kadar kalsium dan fosfor sereal menunjukkan kadar fosfor tertinggi terdapat pada perlakuan $10 \%$ sebanyak $0,14 \%$. Dari ketiga perlakuan, sebenarnya tidak terlihat perbedaan kandungan fosfor yang signifikan. Sedang hasil pengujian kalsium, terlihat perbedaan yang cukup tinggi diantara ketiga perlakuan. Perlakuan yang memiliki kadar kalsium tertinggi adalah perlakuan $10 \%$ dengan $3,80 \%$. Hasil analisis dapat dilihat pada tabel 2 .

Pada hasil uji organoleptic, Sereal control atau sereal jagung tanpa penambahan cangkang serimpingmerupakan sereal yang paling disukai panelis dari segi warna dimana menghasilkan warna kuning keemasan. Warna kuning keemasan pada sereal tanpa penambahan berasal dari kandungan pigmen kuning karoten yang tersimpan dalam endosperm jagung.

Sereal dengan penambahan tepung cangkang kerang serimping sebanyak $10 \%$ merupakan sereal yang paling disukai panelis dari segi rasa, tekstur, dan aroma. Rasa yang didapatkan dari penambahan tepung cangkang kerang serimping sebanyak $10 \%$ adalah manis yang didapat dari gula halus, dan rasa jagung yang khas. Tekstur yang lembut dan renyah saat dimakan didapat dari penambahan tepung tapioka dan tepung maizena.

Tabel 2. Hasil analisis kalsium dan fosfor seral jagung

\begin{tabular}{llll}
\hline No & Jenis FIM & $\begin{array}{l}\text { Kadar } \\
\text { Fosfor } \\
\text { (\%) }\end{array}$ & $\begin{array}{l}\text { Kadar } \\
\text { kalsium } \\
\text { (\%) }\end{array}$ \\
\hline 1 & $\mathrm{~K}_{1} \mathrm{U}_{1}$ & 0,14 & 0,10 \\
2 & $\mathrm{~K}_{1} \mathrm{U}_{2}(0 \%)$ & 0,12 & 0,12 \\
3 & $\mathrm{~K}_{1} \mathrm{U}_{3}(0 \%)$ & 0,13 & 0,11 \\
4 & $\mathrm{~K}_{1} \mathrm{U}_{4}(0 \%)$ & 0,13 & 0,12 \\
5 & $\mathrm{~K}_{1} \mathrm{U}_{5}(0 \%)$ & 0,12 & 0,09 \\
6 & $\mathrm{~K}_{1} \mathrm{U}_{6}(0 \%)$ & 0,14 & 0,10 \\
7 & $\mathrm{~K}_{1} \mathrm{U}_{7}(0 \%)$ & 0,12 & 0,10 \\
& Rata-rata & 0,13 & 0,11 \\
1 & $\mathrm{~A}_{1} \mathrm{U}_{1}(5 \%)$ & 0,13 & 1,30 \\
2 & $\mathrm{~A}_{1} \mathrm{U}_{2}(5 \%)$ & 0,13 & 1,28 \\
3 & $\mathrm{~A}_{1} \mathrm{U}_{3}(5 \%)$ & 0,12 & 1,29 \\
4 & $\mathrm{~A}_{1} \mathrm{U}_{4}(5 \%)$ & 0,11 & 1,29 \\
5 & $\mathrm{~A}_{1} \mathrm{U}_{5}(5 \%)$ & 0,10 & 1,30 \\
6 & $\mathrm{~A}_{1} \mathrm{U}_{6}(5 \%)$ & 0,13 & 1,30 \\
7 & $\mathrm{~A}_{1} \mathrm{U}_{7}(5 \%)$ & 0,12 & 1,27 \\
& Rata-rata & 0,17 & 1,29 \\
1 & $\mathrm{~B}_{1} \mathrm{U}_{1}(10 \%)$ & 0,14 & 3,81 \\
2 & $\mathrm{~B}_{1} \mathrm{U}_{2}(10 \%)$ & 0,14 & 3,79 \\
3 & $\mathrm{~B}_{1} \mathrm{U}_{3}(10 \%)$ & 0,15 & 3,80 \\
4 & $\mathrm{~B}_{1} \mathrm{U}_{4}(10 \%)$ & 0,14 & 3,81 \\
5 & $\mathrm{~B}_{1} \mathrm{U}_{5}(10 \%)$ & 0,12 & 3,83 \\
6 & $\mathrm{~B}_{1} \mathrm{U}_{6}(10 \%)$ & 0,15 & 3,82 \\
7 & $\mathrm{~B}_{1} \mathrm{U}_{7}(10 \%)$ & 0,12 & 3,79 \\
& Rata-rata & 0,14 & 3,80 \\
\hline & & &
\end{tabular}

Pada parameter aroma sereal jagung yang diperkaya cangkang kerang serimping perlakuan control dan $10 \%$ sebenarnya tidak terlalu memiliki perbedaan secara drastis, namun sereal dengan penambahan tepung cangkang kerang serimping terbanyak, aromanya sangat disukai oleh panelis. Hasil analisis organoleptik diperoleh hasil yang ditunjukkan pada Gambar: 1, 2, 3 dan 4 


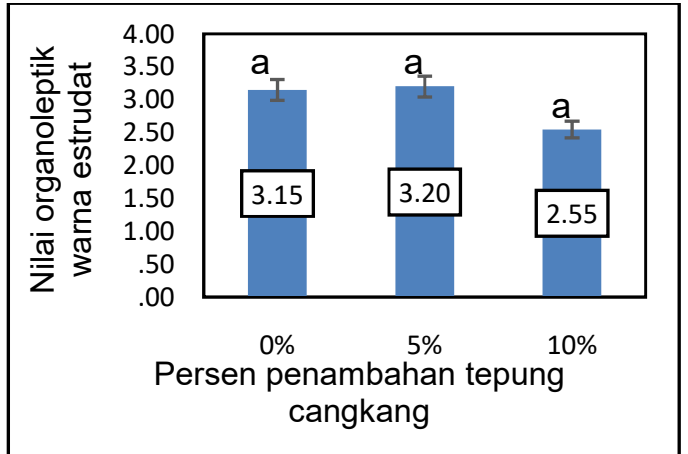

Gambar 1. Rerata hasil Organoleptik terhadap warna Sereal Jagung Kaya Kalsium
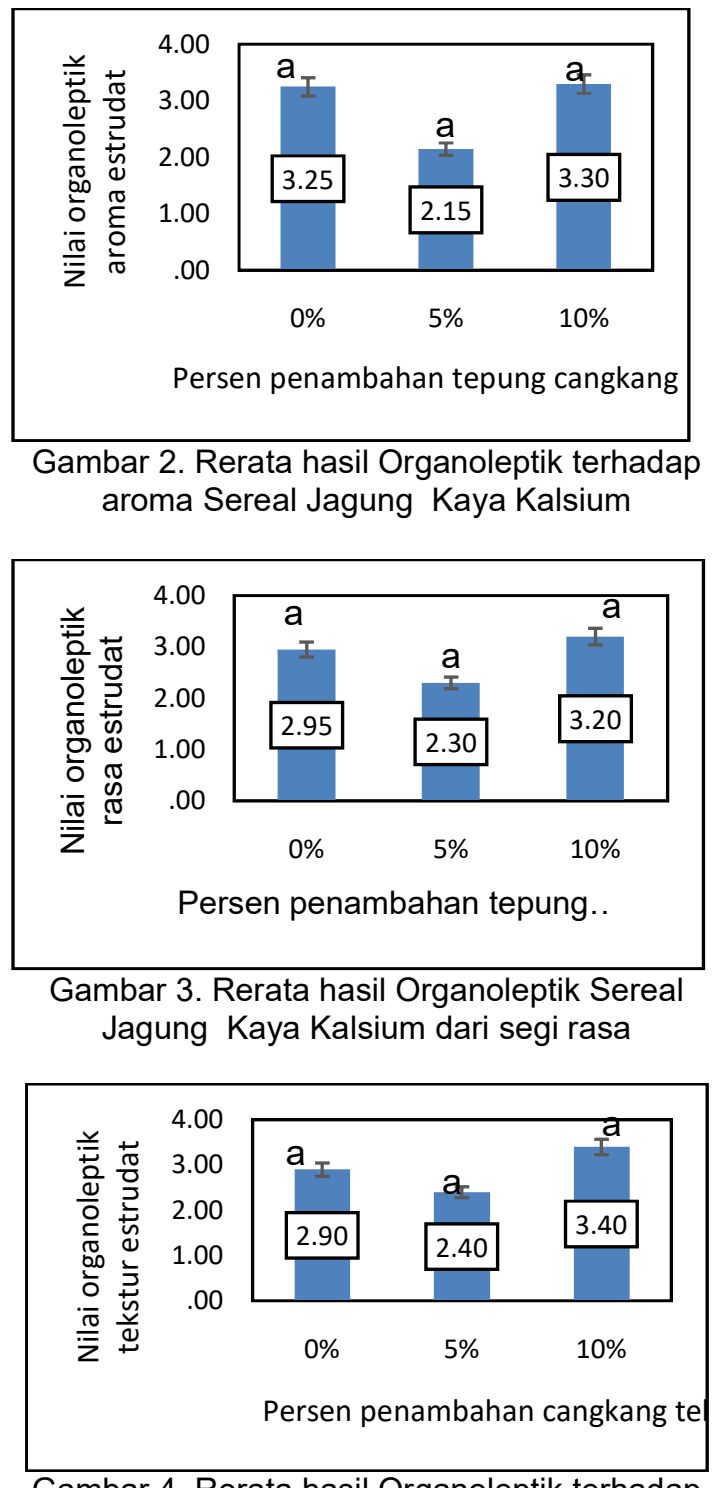

Gambar 4. Rerata hasil Organoleptik terhadap tekstur Sereal Jagung Kaya Kalsium

\section{KESIMPULAN}

Sereal jagung yang ditambahkan tepung cangkang kerang serimping sebanyak $10 \%$ memiliki kandungan kalsium dan fosfor tertinggi yaitu, $3,80 \%$ dan $0,14 \%$. Dari hasil uji organoleptic, sereal yang memiliki daya serap atau daya terima tinggi dari segi aroma, tekstur, dan rasa adalah sereal dengan penambahan tepung cangkang sebanyak $10 \%$.

\section{UCAPAN TERIMAKASIH}

Ucapaan terima kasih disampaikan kepada Belmawa Kemenristek Dikti atas dukungan dana yang diberikan dalam pelaksanaan penelitian ini.

\section{DAFTAR PUSTAKA}

Agustini, T. W., Jusup S., Indah S. Dan Laksmi W., 2009. Pengembangan Produk Snack Kaya Kalsium Berbasis Kerang Serimping untuk lbu dan Anak.Laporan penelitian Hibah World Class University, Lembaga penelitian, Universitas Diponegoro. $31 \mathrm{hlm}$

Agustini,T. W., Ratnawati S.E., Wibowo B.A., Hutabarat J.,2011. Pemanfaatan Cangkang Kerang Serimping (Amusium pleoronectes) Sebagai Sumber Kalsium pada Produk Ekstrudat. Pengolahan Hasil Perikanan. Volume XIV(2) : 132-140

Agustini,T. W., Fahmi A.S., Widowati I., Sarwono A.,2011. Pemanfaatan Limbah Cangkang Kerang Serimping (Amusium pleuronectes) dalam PembuatanCookies Kaya Kalsium. Jurnal Pengolahan Hasil Perikanan. Volume XIV (1) : 8-13

Kiseki, I. 2015. Potensi Komoditi Perikanan Tangkap Kerang Serimping Kabupaten Brebes.

http://beritadaerah.co.id/2015/06/19/po tensi-komoditi-perikanan-tangkapkerang-serimping-kabupaten-brebes/. Diakses tanggal 16 November 2017 
Mulyani, E., 2009. Konsumsi Kalsium. Fakultas Kesehatan Masyarakat Universitas Indonesia, Jakarta. HIm 21-40

Nurhidayanti, A., Dewi S. A., Narsih, 2017. Pembuatan Flakes dengan Variasi Tepung Gandum dan Tepung Kelapa dalam Upaya Peningkatan Mutu Flakes. Jurnal Teknologi Pangan.Volume 8 (2) : 155-162

Ratnawati, S.E., Agustini T.W., Hutabarat J.. Penilaian Hedonik dan Perilaku Konsumen Terhadap Snack yang Difortifikasi Tepung Cangkang Kerang Serimping (Amusium sp.). Jurnal Perikanan (J. Fish. Sci.) Volume XV (2): 88-103

Setyawati, B., Fuada N., Salimar., 2014. Pengetahuan Tentang Osteoporosis dan Kepadatan Tulang Hubungannya dengan Konsumsi Kalsium pada Wanita Dewasa.

Suarni. 2004. Pemanfaatan tepung sorgum untuk produk olahan. Jurnal Litbang Pertanian 23

Utomo, M., Meikawati W., Putri Z.K.,2010. Faktor - Faktor Yang Berhubungandengan Kepadatan Tulangpada Wanita Postmenopause. JurnalUniversitas Muhammadiyah Semarang. Volume 6 (2) : 1-10

Waty, M.,2009. Metabolisme Kalsium dan Tulang.http://hilwana90.blogspot.co.id/ 2009/03/metabolisme-kalsium-dantulang.html. Diakses pada tanggal 16 November 2017. 